\title{
Pipes, Levers, Walls, Rocks and Water: The Architecture of Niagara Falls
}

\author{
JESSICA COLANGELO \\ University of Arkansas
}

The phenomenon of global climate change has brought about a pressing need for designers and architects to rethink how we construct relations between humans and the earth. A technology-based approach has been the primary tool of the building industry to engage climate change through performative building systems. While this approach is significant for lowering the carbon footprint of singular buildings, it does not alone offer an adequate model for architecture to address the increasing concerns of climate change. To examine the potential for architecture to form new relationships between the natural and the built environment, this paper traces the history of one of the largest artificial landforms in the United States - Niagara Falls. As a technology-laden hyper-designed earthwork-fountain, Niagara Falls is an imaginative resource for architects to further a cultural and aesthetic approach towards issues of climate justice.

\section{INTRODUCTION}

In the winter of 2016, a series of news articles announced New York State's 2020 proposal to dewater the American side of Niagara Falls. The news headlines read: "New York is going to turn off Niagara Falls. Here's how," " "It's surprisingly easy to turn off Niagara Falls," 2 "Silencing Niagara Falls: New York plans to temporarily dry up the roaring cascade." ${ }^{13}$ The headlines entice with a sense of awe, wonder and slight disbelief at human's collective power to alter the currents of the mighty Niagara River. But this sensation is quickly tempered, as each headline is followed with historic photographs from 1969 depicting the very same riverbed dried out and undergoing similar maintenance (figure 1). Despite knowing that Niagara Falls has been tamed for centuries, in ways far more elaborate than a temporary dam, we still remain skeptical of our own ability to control it.

The phenomenon of global climate change has brought about a pressing need for designers and architects to rethink how we construct relations between humans and the earth. ${ }^{4} \mathrm{~A}$ technology-based approach has been the primary tool of the building industry to engage climate change through performative building systems. While this approach is significant for lowering the carbon footprint of singular buildings, it does not alone offer an adequate model for architecture to address the increasing concerns of climate change. ${ }^{5}$

Outside of the architecture discipline, a growing number of scholars are calling attention to climate change as not merely a scientific problem, but increasingly a cultural, social and political one. Mike Hulme, a Human Geographer at the

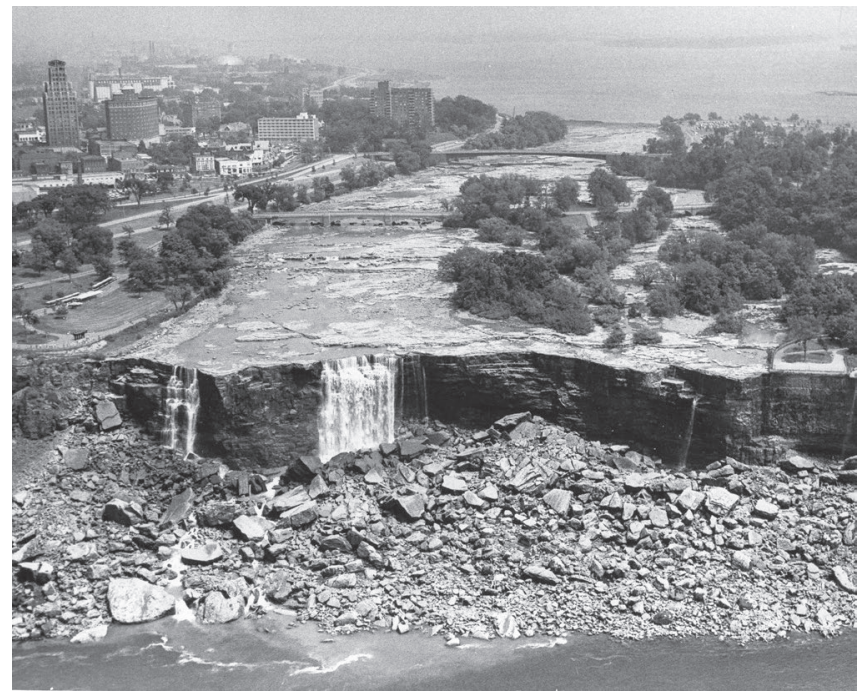

Figure 1. Niagara Falls dewatered. June 21, 1969. Associated Press (AP).

University of Cambridge, proposes that climate change is "not a 'problem' waiting for a 'solution',"6 and that instead climate change can be utilized to open up larger questions and opportunities for how humans relate to the earth. Hulme writes:

Rather than catalyzing disagreements about how, when and where to tackle climate change, the idea of climate change should be seen as an intellectual resource around which our collective and personal identities and projects can form and take shape. ${ }^{7}$

Hulme emphasizes that climate change cannot be understood through any single perspective, but instead in its multiplicity of readings, the phenomena has the capacity to become an "imaginative idea" which can enable new approaches and thinking to emerge. ${ }^{8}$

Furthering the case for an approach to climate change outside of solely technology-based solutions, author Naomi Klein argues in her book This Changes Everything: Capitalism vs. the Climate that the main challenge confronting climate change is the very systems put in place that support capitalism. Klein writes:

What the climate needs to avoid collapse is a contradiction in humanity's use of resources; what our economic model demands to avoid collapse is unfettered expansion. Only one of these rule sets can be changed, and it's not the laws of nature. ${ }^{9}$ 
Klein's book serves as a rallying call to mobilize climate change as a medium to provoke positive cultural shifts that could aid in the fight towards climate justice.

Within this context, I propose that architects have a renewed agency in the discourse on climate change. If the architect's role is not solely to operate through performance-based design models, what methods are there for architects to address climate change as a cultural project? What opportunities are there for architecture to engage in climate change as an imaginative and intellectual resource?

To examine the potential for new relationships between the natural and the built environment, this paper traces the history of one of the largest artificial landforms in the United States - Niagara Falls. As a technology-laden hyper-designed earthwork-fountain, Niagara Falls is an imaginative resource for architects to rethink our relationship to earth. The history of Niagara Falls parallels the environmental history of the United States through a balancing act between conservationist ideals and capitalist exploitation. This duality has built Niagara Falls as a site of spectacular geologic, geographic and atmospheric imagination at an extraordinary scale. This imagination is portrayed not merely through stories and paintings, but as this paper will outline through a history of diplomacy, policy, economy and physical infrastructure.

The development of Niagara Falls through the nineteenth and twentieth century can be read through three distinct lens that frame the shifting view of nature at the falls: the myth of nature, the specification of nature and the illusion of nature. These three attitudes towards nature each defined a separate era in the design and construction of the architecture of Niagara Falls.

\section{THE MYTH OF NATURE}

With 168,000 cubic meters of water per minute barreling over 170-foot cliff Niagara Falls is one of the largest waterfalls in the world by volume. And from early habitation of the area Europeans looked to harness the Falls great power. The first person to use the Falls for power was a Frenchman named Daniel Joncaire, who in 1757 dug a ditch on the edge of the upper rapids and built a small sawmill. ${ }^{10}$ By the 1800's land speculators saw great potential for the future of Niagara as a hub for industry and brothers Augustus and Peter B. Porter purchased the land along the American side of the falls and began work on a power canal. Augustus Porter worked with a civil engineer to design a 4,400-foot power canal that would divert water from the upper rapids to the riverbank just below the falls ${ }^{11}$ By 1861 , the power canal was complete and offered factories direct access to place their waterwheels in the rushing currents of the Niagara River. By 1885, the area had become heavily industrialized and became known as the "milling district." The factories combined used all of the canals 10,000 horsepower of potential energy and the elevation of the Niagara gorge became covered in tailraces, water from the watermill's runoff. ${ }^{12}$
The quick rise in industrial development prompted early conservationist efforts to turn attention to the Falls. Frederick Law Olmsted, after returning to New York from working on conservation efforts at Yosemite Valley in California, led the charge for conservation at the Falls through a small but vocal group named the "Free Niagara" movement. The group was concerned with the aesthetic disfigurement of the falls from the industrial and commercial development, as well as the privatization of land which was limiting access and enjoyment by the public. The industrialization was not only a physical problem for the conservationists but also a problem of aesthetic sensibility. By this time, a new class of tourists had been coming to view the falls and take part in the cheap amusements. Many travelers would view the falls from their carriage or be met by solicitors to pay a small fee to look at the falls through a peephole. In addition, commercial programming such as art galleries, ballrooms, and theaters were being built near the small park on the American side of the Falls. Olmsted and other members of the movement viewed these new constructions as "degraded" amusements and not the appropriate way to view a natural wonder of the world.13 In establishing institutionalized values, distinctions had to be made between high and low culture, and the nostalgic image of an undisturbed nature provided moral counter to the organic accumulations of capital that comprised the present day scenery.

The Free Niagara movement culminated in the 1879 Preservation of Scenery Report, a special report addressed to the New York State legislature by Olmsted and the New York State survey director James T. Gardner. The report included a detailed petition and plan for the reservation of land surrounding Niagara Falls and requested the establishment of a State Park that could be open and free to the public. As stated in the beginning of the document, the report was commissioned by the state to:

[A]scertain how far the private holding of land about Niagara Falls has worked to public disadvantage through defacements of the scenery; to determine the character of such defacements; to estimate tendency to greater injury; and lastly, to consider whether the proposed action by the State is necessary to arrest the process of destruction and restore the scenery to its original character. ${ }^{14}$

The report details the degradation of scenery surrounding the falls, the worrisome effects of commercialization and privatization and the new plans for the acquisition and reservation of parkland through eminent domain. It vividly depicts the current state of the scenery at Niagara Falls as fallen into a state of disrepair, with illustrations showing the "disfigurement of the shoreline" and "repulsive scenery." To counter these degraded images, an illustration of a natural wild river bank is juxtaposed and titled "An Ideal View of the American 
Rapids After the Village Shore and Bath Island are Restored" (figure 2). The proposal advocated for the removal of artificial structures from the view surrounding the falls by reserving a 200-foot strip of wilderness between the river and the urban area, removing the existing buildings along the river's edge. This is illustrated in a master plan of the proposed land reservation and a table of purchasing costs for the state to acquire the land from private interests. Establishing boundaries between what could be natural and not, and framing views within those boundaries reinforced the importance of the scenic image of an idealized nature for the conservation team.

This nostalgic desire proved to be an effective instrument for mobilizing political will. In 1885 New York approved Olmsted's vision and created the first State Park in the United States, and following Ontario designated the land on the Canadian side of the river as the Queen Victoria Park. In the forthcoming years Olmsted and his partner Calvert Vaux would develop plans for the layout of the first American State Park. ${ }^{15}$ Olmsted and

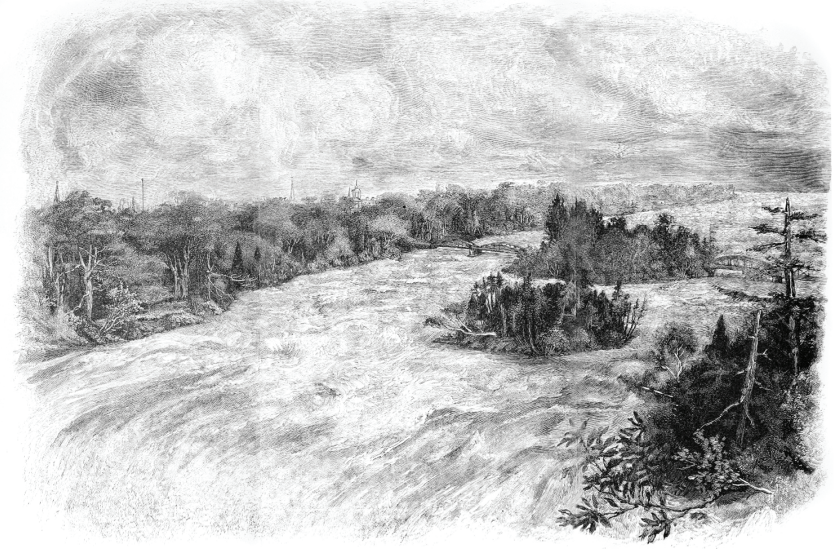

Figure 2. "An Ideal View of the American Rapids After the Village Shore and Bath Island are Restored," from the Special Report of New York State Survey on the Preservation of the Scenery of Niagara Falls, 1880.

Vaux's design of the American Falls State Park filled in large amounts of land that had been developed as canals along the Niagara riverfront and formed a distinct delineation between the new pristine nature of the falls and the industrial development surrounding it. The new landscape of the Falls and their surrounding scenery became a myth of themselves, a constructed terrain meant to emulate a past image of humans apart from nature.

\section{NATURE AS SPECIFICATION}

While the Olmsted plan set strict guidelines for the visual appearance and management of the land immediately surrounding the river, it set no restrictions for the use of the water or riverbed itself. And with the invention of alternating current by Nikolas Tesla at Niagara Falls in 1890, which allowed for the affordable transmission of electricity over great distances, New York and Ontario began to actively pursue new strategies to divert greater amounts of water from the falls to increase hydro-electric power production. With the State Park reservation intact and an increased desire to divert water from the river, the early 1900's initiated a series of studies and exchanges between the power companies and an international Niagara Board that managed concerns over the appearance of the falls. In addition to concern over the appearance of water volume over the falls, the rate of erosion of the rock face itself was worrisome to conservationists.

Following multiple years of surveys conducted at the Falls, geologists had discovered that the falls were receding at a rate of approximately three feet per year ${ }^{16}$ This study gave power companies a new position, and they argued that the water diversion could actually reduce the rate of recession. ${ }^{17}$ At this moment we begin to see the leadership of scenic program of the falls shift hands from the activists aesthetes to the bureaucrats and managers within governance and the power companies. The very interests that had been responsible for the first wave of degradation of the Falls had now been institutionalized as the aesthetic authority.

In 1923, a special board was established to conduct an updated scenery report titled the "Preservation and Improvement of the Scenic Beauty of Niagara Falls and Rapids." The report sought to systematically quantify the "scenic grandeur" of the falls. ${ }^{18}$ The report, though outwardly admitting the impossibility of quantifying the experience of the falls due to its subjectivity, creates an itemized list of the features the board agrees contributes to the scenery. This includes commentary on the height of the cliffs, volume of water, level of sound, color of water, mist and visibility. The report catalogs both the physical elements that make up the scenery, including the rapids above the falls, Niagara Falls, the Maid-of-the-Mist Pool, the whirlpool and lower rapids, as well as the atmospheric effects, such as winter effects, color effects, and the surroundings. In addition the board enlisted a color physicist to conduct a scientific report on the effects of water flow and volume on the color of the water. ${ }^{19}$

The report concluded that the optimum waterfall to "insure maximum persistence of the color curtain for this conservative minimum depth of 5 feet would be not greater than 12 feet per second." 20 Taking into account the various factors that make up the scenic grandeur at the falls the report states:

It seems to be a fact that perhaps more than half of the water flowing over this cataract (the Horseshoe Falls) adds nothing at all to the grandeur unless it be somewhat in the form of noise. ${ }^{21}$

Following the report, continued talks between the United States and Canada attempted to reconcile the need for power supply and the scenic spectacle. ${ }^{22}$ During World War II, the countries agreed to allow increased diversion of the water for wartime needs, allowing 5,000 cubic feet per second (cfs) 


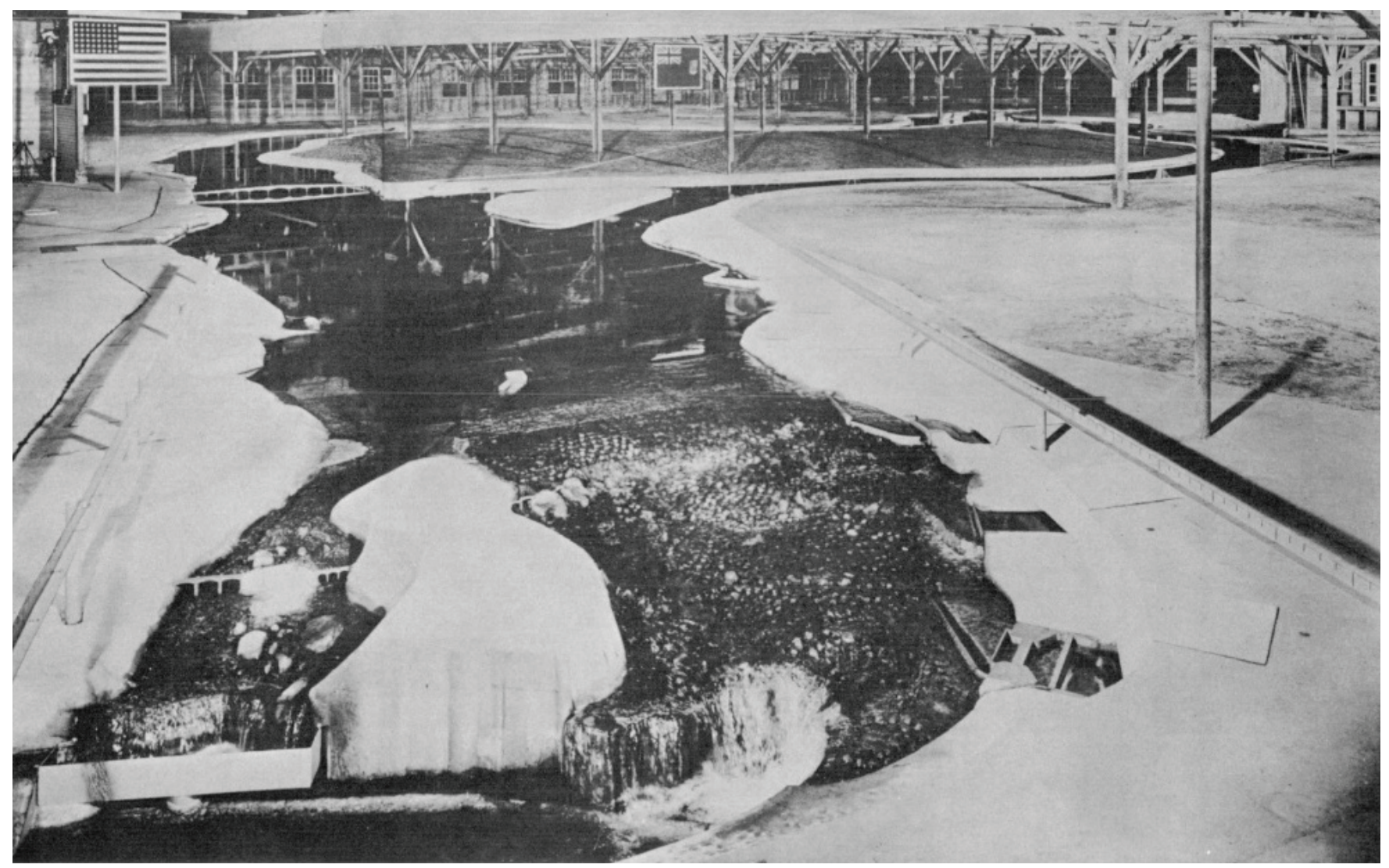

Figure 3. Niagara River and Falls model by Waterways Experiment Station, from Preservation and Enhancement of Niagara Falls: Hydraulic Model Investigations, U.S. Army Corps of Engineers, 1955

for the United States and 3,000 cfs for Canada. ${ }^{23}$ However, following the end of WWII both sides continued to divert the additional amount of water from the falls. The major legislative act that looked to reconcile the scenery and the water diversion came in 1950 with the Niagara River Water Diversion Treaty. The treaty established guidelines for the amount of water that could be diverted from the river at any given time, as both governments agreed to recognize "their primary obligation to preserve and enhance the scenic beauty of the Niagara Falls and River and, consistent with that obligation, their common interest in providing for the most beneficial use of the waters of that River." ${ }^{\prime 24}$ The amount of water diversion allowed was based on the popular tourism times, with increased water flow over the falls in the daytime and summer months and increased diversion from the falls in the night and winter. Under the Niagara Treaty, the countries combined could now divert up to $75 \%$ of the water at night time and winter months and $50 \%$ of water in the tourist peak hours. ${ }^{25}$ The aesthetic management of Niagara Falls is now a matter of international diplomacy.

Following the treaty, studies were conducted by the International Niagara Falls Engineering Board to study the effects of the water diversion on the appearance of the falls. With the amount of water diversions that were allowed under the treaty the upper river had dropped four feet in depth, large areas of the river bed had become exposed and at times water would not even cover the entire Horseshoe crest. ${ }^{26}$ The board concluded that without remedial works to the river bed there would be a noticeable impact on the falls scenic beauty and scale models were built in the United States and Canada to study the design for the river remediation projects. ${ }^{27}$

The U.S. Army Corp of Engineers commissioned a 260-foot long model of the falls which included the upper reaches of Niagara River in Vicksburg, Mississippi (figure 3). The scale model was 360:1 horizontal and 60:1 vertical. ${ }^{28}$ And Ontario Hydro built an indoor model at its Islington Station which included 5 miles of the river from Grand Island to the Rainbow Bridge. Using the models, the team developed a series of strategies that would help to raise the water level and spread it evenly across the riverbed and crest line of the falls. This would include underwater weirs up stream of the falls to raise the water level, a linear dam with a series of sluice gates to control the amount of water in certain areas of the river as water flowed towards the Horseshoe Falls crest, and a 4 feet deep, 94,000 cubic yards of excavation at the sides of the Horseshoe Falls to allow for an evenly distributed water flow over the falls. ${ }^{29}$ 
The same techniques of landscape manipulation and resource management that had been cited for the degradation of the Falls in the 19th century were fully institutionalized and deployed to maintain a balance between scenery and production. While the scenic ideals remained rooted in nostalgia, the technologies of production continued to evolve. The means for evaluating the scenic beauty then became comically subsumed by the mechanisms of production to a point in which romanticism became a scientifically quantifiable. The beauty of Niagara Falls became an outline specification, which included sections for water volume, spread, color, and of course energy production.

\section{NATURE AS ILLUSION}

In addition to the management of the water flow at the falls, the land around the falls was also taken into consideration for safety and elevation of the touristic experience. In 1931, a large rock slide at the American Falls left a pile of rock talus that reached half way up the cliff face and raised concern over the appearance of the Falls and the stability of the cliffs. Subsequently, another large rock fall occurred in 1954 at a popular tourist outlook on the American side called Prospect Point. The rock fall caused concern over the safety for visitors to the falls and both the Canadian and American parks worked to stabilize the rock face. This included the demolition of iconic rocky outcrops, such as Table Rock, and the structural reinforcement of others including a 835 -foot retaining wall at Terrapin Point. ${ }^{30}$ At this point the technological supports for the scenic spectacle became so ubiquitous that they were almost hiding in plain sight.

In 1956, the American Schoellkopf Power Station unexpectedly collapsed from water intrusion behind its retaining wall that eroded the rock foundations behind and caused a landslide. Following the collapse, New York Power Authority drafted plans for the Niagara Power Project, a brand new and higher capacity power station more similar to the recently built Canadian plants. The extensive project was completed in 1961 and included two 4-mile long underground conduits that carried water from the upper Niagara River to the Lewiston Reservoir and the Robert Moses Power dam. ${ }^{31}$

With the 1954 rock slide at Prospect Point and the 1956 landslide at the power station still in mind, public concern continued to grow over the stability of the cliffs and the shifting appearance of the water falls. Large chunks of talus still remained piled halfway up the falls and some believed another rock slide would cause the falls to "choke" themselves. ${ }^{32}$ In 1969, the International Joint Commission undertook a field study to look for ways to stall the erosion of the falls. For geologists to examine the rock, the United States Army Corp of Engineers built a temporary cofferdam from the eastern end of Goat Island to the American shore. The dam diverted all of the Niagara River to Horseshoe Falls and literally turned off the American Falls. The dewatering allowed scientists to map and photograph the riverbed, cliff face and talus. ${ }^{33}$

Discoveries from the 1969 dewatering and further studies on the appearance of the American Falls were later published in a 1971 report titled the Preservation and Enhancement of the American Falls at Niagara. The report, published by the International Joint Commission, included an appendix titled "Aesthetics" documenting the team's in depth study of the appearance of the American Falls. ${ }^{34}$ Working off of public concern over the talus from the 1931 rock slide, a large-scale mock-up of the American Falls was constructed with help from Ontario Hydro to test different options for talus place-

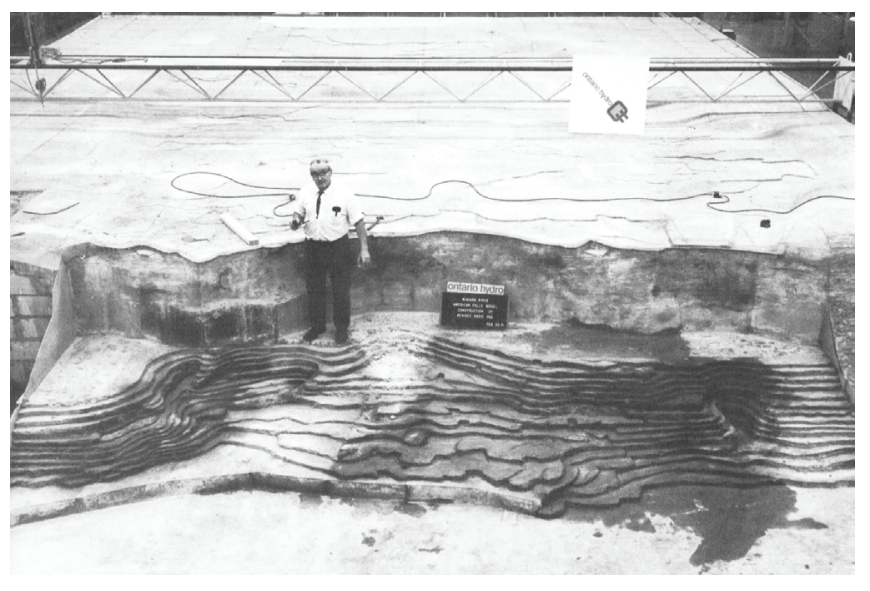

Figure 4. Model of the American Falls by the Hydro-Electric Power Commission of Ontario, from Preservation and Enhancement of the American Falls at Niagara: Interim Report to the International Joint Commission, 1971.

ment and possible remova ${ }^{35}$ (figure 4). The report describes the technique used as the study of a large water sculpture to explore "Water and Rock as Elements of the Composition." ${ }^{\text {"36 }}$ The model was used to document photographs of eight different scenarios for the talus placement, ranging from leaving the falls untouched to removal of all talus below (figure 5).

A survey was conducted utilizing photographs of the model and popular opinion was to remove all talus from beneath the falls to enhance the height and overall "majestic" quality, however the team was still stuck in a philosophical dilemma identified as an issue of "process vs. product." ${ }^{37}$ If they remove the talus and stabilize the rock face, they would be intervening in the natural process of erosion, but if there continued to be rock slides the American Falls could end up as more of a rocky cascade than a grand waterfall. Noting that "to 'preserve and enhance the beauty of the Falls' does not mean that they should be frozen dead in their present appearance," the team concludes the most logical outcome 


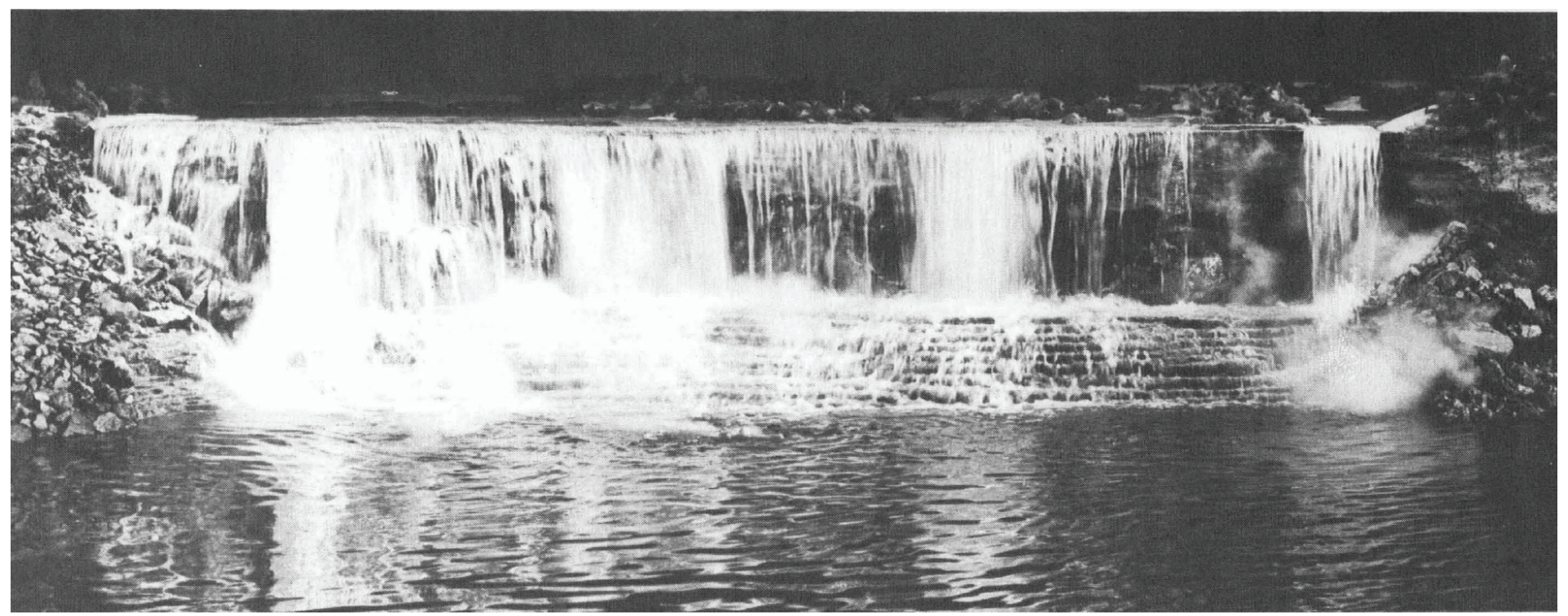

Figure 5. Model photo of the American Falls with "All talus removed from the bedrock," from the Preservation and Enhancement of the American Falls at Niagara: Interim Report to the International Joint Commission, 1971.

may be to remove the existing talus, but not stabilize the rock. ${ }^{38}$ However, due to cost and structural concerns, no work was ever done to remove the talus, though parts of Goat Island and Luna Island rock face had already been stabilized as part of the 1969 dewatering effort. ${ }^{39}$

Though never implemented, the study was an honest and imaginative effort to design an illusion of grandeur. The study was able to objectively view the American Falls as a constructed architecture, built for aesthetics, safety and pleasure, and seen in need of repair and renovation.

\section{CONCLUSION}

The history of Niagara Falls is filled with feats of human innovation. It is the site of technological advancement (invention of alternating current), as well as imaginative interventions on the geological (the stalling of erosion), geographical (the shaping of lands), and atmospheric (the control of water and mist) scale. The pipes, levers, retaining walls, reinforced rocks and regulated water flow comprise the architecture of the Falls, and together they generate an architecture that orchestrates the form and experience of the great cataract while quietly powering 3.8 million homes. ${ }^{40}$

The design of Niagara Falls is distinct from other large-scale infrastructure projects in that the design motivations display a consistent return to aesthetic agendas. Even though significant technological and performance-based projects of electrical and civil engineering were consistently being developed and constructed downstream of the Falls, the cultural project surrounding the appearance of the Falls never left the conversation and if anything grew in importance to the Falls many constituents. If we return to Hulme's argument that climate change can be thought of as a cultural problem as much as a scientific one, the architecture of Niagara Falls begins to open up a dialog between the technological apparatus that promote sustainable building practices and the aesthetic drivers required to launch these practices into a wider cultural discourse.

\section{ENDNOTES}

1 Eric Adams, "New York is Going to Turn Off Niagara Falls. Here's how," Wired, January 29, 2016. https://www.wired.com/2016/01/ new-york-is-going-to-turn-off-niagara-falls-heres-how/.

2 Alissa Walker, "It's Surprisingly Easy to Turn Off Niagara Falls," Gizmodo, January 25, 2016. https://gizmodo.com/ its-surprisingly-easy-to-turn-off-niagara-falls-1755006653.

3 Rose Hackman, "Silencing Niagara Falls: New York Plans to Temporarily Dry Up the Roaring Cascade," The Guardian, February 1, 2016. https://www. theguardian.com/us-news/2016/feb/01/silencing-niagara-falls-new-york-plansto-temporarily-dry-up-the-roaring-cascade.

4 For an overview of the various ways climate change impacts architecture see Amale Andraos, "What Does Climate Change? (For Architecture)," Climates: Architecture and the Planetary Imaginary, ed., James Graham and Caitlin Blanchfield, (New York: Columbia Books on Architecture and the City, 2016), 297-302

5 For a summary of the risks and impacts of climate change see Intergovernmental Panel on Climate Change, Climate Change 2014 Synthesis Report Summary for Policymakers, accessed September 20, 2018. http://ipcc.ch/pdf/assessmentreport/ar5/syr/AR5_SYR_FINAL_SPM.pdf.

6 Mike Hulme, "Why We Disagree about Climate Change," accessed September 20, 2018. https://mikehulme.org/wp-content/uploads/2009/10/HulmeCarbon-Yearbook.pdf.

7 Mike Hulme, Why We Disagree about Climate Change: Understanding Controversy Inaction and Opportunity (Cambridge, UK: Cambridge University Press 2009), 326.

8 Hulme, 329

9 Naomi Klein, This Changes Everything: Capitalism vs. the Climate (New York: Simon \& Schuster, 2014), 21

10 Michael T. Taylor and John W. Townsend, Rapid Excavation and Tunneling Conference: 2007 Proceedings (Colorado: Society for Mining, Metallurgy, and Exploration, 2007), 186.

11 Ginger Strand, Inventing Niagara: Beauty Power and Lies (New York: Simon \& Schuster, 2008), 140.

12 Strand, 140.

13 Strand, 144.

14 James T. Gardner and Frederick Law Olmsted, Special Report of New York State Survey on the Preservation of the Scenery of Niagara Falls (Albany: Charles van Benthuysen \& Sons, 1880), 3 
15 Lee Hall, Olmsted's America: An "Unpractical" Man and His Vision of Civilization (United States: Bulfinch Press, 1995), 185.

16 American Falls International Board, "Appendix B-Aesthetics," Preservation and Enhancement of the American Falls at Niagara, Interim Report to the International Joint Commission, Appendix B-Aesthetics, December 1971, p. 9 , accessed September 20, 2018. http://www.ijc.org/files/publications/N13.pdf.

17 Ginger Strand, "Niagara Power," Ginger Strand official website, accessed September 20, 2018. http://www.gingerstrand.com/niagara_power.htm.

18 Special International Niagara Board, Preservation and Improvement of the Scenic Beauty of the Niagara Falls and Rapids (Washington: United States Government Printing Office, 1931), 29.

19 Special International Niagara Board, 31

20 Special International Niagara Board, 34.

21 Special International Niagara Board, 30.

22 Daniel Macfarlane, "'A Completely Man-Made and Artificial Cataract': The Transnational Manipulation of Niagara Falls," Environmental History 18 (October 2013): 766.

23 Macfarlane, 768.

24 Treaty between Canada and The United States of America Concerning the Diversion of the Niagara River, signed at Washington, February 27, 1950, 4.

25 Treaty between Canada and The United States of America Concerning the Diversion of the Niagara River, 6.

26 Strand, Inventing Niagara, 191.

27 Macfarlane, “'A Completely Man-Made and Artificial Cataract,'” 770.

28 Daniel Macfarlane, "Model Environments: Engineering the Niagara and St. Lawrence Megaprojects," Niche: Network in Canadian History and Environment, accessed January 8, 2017, http://niche-canada.org/ 2016/08/24/ model-environments-engineering-the-niagara-and-st-lawrence-megaprojects/.

29 Strand, Inventing Niagara, 191.

30 Strand, 195.

31 New York Power Authority, "The Niagara Power Project: Clean Energy for NY," accessed September 20, 2018. https://www.nypa.gov/power/generation/ niagara-power-project

32 American Falls International Board, "Appendix B-Aesthetics."

33 American Falls International Board, 11-15.

34 American Falls International Board.

35 American Falls International Board, 19-21.

36 American Falls International Board, 11.

37 American Falls International Board, 32-33.

38 American Falls International Board, 33.

39 Ginger, Inventing Niagara: Beauty Power and Lies, 193.

40 New York Falls, "Electrical Power Generation at Niagara," accessed on September 20, 2018. http://nyfalls.com/niagara-falls/faq5/. 